\title{
DRIVING IN THE MIDDLE OF THE ROAD: PARADOXES OF WOMEN'S ROLE UNDER THE NEW SAUDI ARABIAN NATIONALISM
}

Luiza Cerioli*

\begin{abstract}
King Salman and prince Mohammad bin Salman yearn to shift Saudi Arabia away from oil dependency via the project Vision 2030, which includes a set of liberalisations for women, such as legalisation of driving and economic empowerment. Topics related to women have been a taboo to Saudi society; thus, it is interesting to understand their role in these reforms and their negotiation of rights within the state. I argue that these reforms are not politically liberalising, as they do not rearrange the patriarchal structure. Moreover, they walk in line with a top-down nationalist project that excludes and arrests, among others, female activists that previously fought for the right to drive, stressing the limitations on women's freedom under Salman's rule.

Keywords: Saudi Arabia, international status, Vision 2030, nationalism, autocratic liberalization.

\section{Resumo}

Conduzir dentro dos limites: contradições no papel das mulheres no contexto do novo nacionalismo saudita

O rei Salman e o príncipe Mohammad bin Salman ambicionam modernizar a Arábia Saudita, tornando-a menos dependente do petróleo através do projeto Saudi Vision 2030, que inclui um conjunto de liberalizações para as mulheres, como o direito de conduzir e a promoção da participação económica. O direito das mulheres é tabu na sociedade saudita, por isso, é interessante entender o seu papel nas reformas e a forma como negociam direitos. Argumento que as reformas não são liberalizadoras uma vez que não abordam a estrutura patriarcal do Estado. Além disso, estão em linha com um projeto nacionalista do governo que exclui e aprisiona, entre outros, as mulheres ativistas que antes lutaram pelo direito de conduzir, destacando, assim, as barreiras que as mulheres enfrentam sob o governo dos Salman no que tange à sua liberdade.
\end{abstract}

Palavras-chave: Arábia Saudita, estatuto internacional, Vision 2030, nacionalismo, liberalismo autocrático.

DH Center for Near and Middle Eastern Studies (CNMS) at the University of Marburg, 35037 Marburg - Hessen, Germany.

Address: Deutschhausstraße 12, 35037 Marburg — Hessen, Germany.

Electronic address: luizacerioli@gmail.com

ORCID ID: https: / / orcid.org/0000-0003-3650-8378 


\begin{abstract}
Resumen
Conduciendo dentro de los límites: contradicciones del rol de las mujeres en el contexto del nuevo nacionalismo saudí

El rey Salman y el príncipe Mohammad bin Salman ambicionan alejar Arabia Saudita de la dependencia del petróleo a través del Vision 2030, un proyecto que tiene un conjunto de reformas liberalizaciones, incluso para las mujeres, permitiéndoles conducir y promoviendo su participación económica. El derecho de las mujeres ha sido un tabú para la sociedad saudita; por lo tanto, es fundamental comprender su papel en las reformas y su negociación de derechos con el Estado. Argumento que las reformas no son políticamente liberalizadoras pues no abordan la estructura patriarcal del Estado y se alinean con el proyecto nacionalista, que excluye y aprisiona, entre otros, las mujeres activistas que lucharon antes por el derecho a conducir, enfatizando así las limitaciones a la libertad de las mujeres bajo el gobierno de los Salman.
\end{abstract}

Palabras-clave: Arabia Saudita, estatuto internacional, Vision 2030, nacionalismo, liberalismo autocrático.

\title{
Introduction
}

King Salman's transformation plan Vision 2030 seeks to reframe Saudi Arabia as an emboldened, modern nation, preparing the country to a post-oil future. His son, Crown Prince Mohammad bin Salman (also known as MBS) is the plan's mastermind and chief spokesperson, promoting, both domestic and internationally, a new country, which is to be more attractive to foreign capital and visitors, and closer to western patterns of modernity and development (AlRasheed 2018a, 251; Krane 2019, 121). Under their watch, the religious police lost authority, cinema and gender-mix concerts were legalised, and women were allowed to drive. These produced encouraging responses from mainstream media, especially the last one, as women liberalisation measures are associated with a global standard of civilisation. On the international community, expectations about proper relations between women and state institutions are used as markers to distinguish so-called «civilised» and «western» societies from others (Towns 2009, 682). Taking stock of these several changes, I focus on the interface between women's long-awaited authorisation to drive and Saudi Vision 2030.

I argue that Saudi Vision 2030 works not only as a tool to consolidate the prince's hold on power but also as a top-down social engineering policy to reorient state-society relations. Since the death of its founder, Abdul-Aziz, the kingdom has always been under the rule of his sons. The ascension of MBS to power is, hence, the first generational change since 1953 and that has created many expectations, hopes and anxieties over the future of the regime (AlRasheed 2018a). He corresponds to a new generation of rulers, and he aspires to change Saudi Arabia by promoting entrepreneurship, modernisation, foreign investment and privatisation (Krane 2019, 122). 
MBS is also the promoter of a new nationalism that is disconnected from the unified religious ethos and based on a tale of a nation destined to play a grandiose role (AlRasheed 2018a, 11; Doaiji 2018, 131; Alhussein 2019). Reasserting the centrality of the state via a new sense of pride of belonging, it calls for people to participate in social-economic changes altering the traditional rentier social contract that had, for decades, guaranteed regime legitimacy (Niblock 2006; Ennis 2019; Jones 2019). I reason that the liberalisations for women must be understood in this context and that, despite improving Saudi's global status, they are under the wings of this new nationalism that, due to its exclusionary features, can actually damage the kingdom's international image in the long run.

Saudi women are submitted to a male guardianship system (wali), which deprives them of autonomy: they depend on men to access services, undergo medical procedures, open bank accounts, among others (AlRasheed 2013; Doaiji 2018). Therefore, the overall positive reaction to the lifting of the ban, from Saudis and western media, is understandable. Saudi activist Manal al-Sharif (2019), co-founder of the Woman2Drive movement, said that everyone was «so hopeful with the lifting of the ban. It was a huge step for us». International news vehicles, such as The Guardian, Arab News and The Independent, reported on MBS with an enthusiastic tone, endorsing him as a reformer and moderniser. ${ }^{1}$ The New York Times even praised MBS for leading a «top-down Arab Spring» (Friedman 2017). However, liberalising policies by autocratic regimes do not tend towards democratisation (Brumberg 2002; Levitsky and Way 2010; Jones 2015). The imprisonment of well-known Saudi female activists, the increasing number of women runaways and the general crackdown on dissent since 2018 put into question the progressiveness of the Salmans' agenda.

I suggest that the liberalisation measures are progressive only if in tandem with this new nationalism. Saudi women can now link their cause to citizenship whereas before most demands for progressive policies were perceived as confrontation. However, that does not mean that the reforms promote empowerment beyond the patriarchal delimitations of the authoritarian state. They can actually limit ambitions for global status. To support this account, I first work on the interaction between autocratic liberalisation and status-seeking behaviour; second, I explain elements of Saudi Vision 2030 crucial for the analysis; third, I describe the efforts of female driving activists; fourth, I explore the relationship between

«This is a revolution: Saudis absorb crown prince's rush to reform», Martin Chulov, The Guardian, November 7, 2017. Available at: <https://www.theguardian.com/world/2017/nov/07/ this-is-a-revolution-saudis-absorb-crown-princes-rush-to-reform>; «Saudi women take the wheel, test-driving a new freedom», Deema AlKhudair, Arab News, March 7, 2018. Available at: <https://www.arabnews.com/node/1261366/saudi-arabia»; «Saudi Arabia has lifted the ban on women driving - this is what it means for women's rights», Najah Al Otaibi, The Independent, June 24, 2018. Available at: <https:/ / www.independent.co.uk/ voices / saudi-arabia-women-driving-ban-lifted-female-rights-riyadh-middle-east-a8414281.html>. 
women and the Vision 2030; and, finally, I display the growing authoritarianism in Saudi Arabia, concluding with the adverse effects of nationalism over the sought for status. I draw from a range of specialised authors, several online reports and news of the recent events; however, it is crucial to recognise my limitations on accessing information on this topic.

\section{Autocratic liberalisation and the pursuit for status}

The lift of the ban in September 2017 was a manifestation of autocratic liberalisation, meaning a tactical political opening corresponding to liberal ideas (Brumberg 2002, 56). Rationalist understandings of autocratic liberalisation argue that their goal is to sustain, rather than transform, the regime, representing controlled moves that serve self-interests (Brumberg 2002, 54; Levitsky and Way 2010). Hence, states reduce pressure and alter dynamics of their social contract, re-establishing legitimacy without changing order (Levitsky and Way 2010). Such liberalisations can contain personal motivations, alluding to a ruler's experiences or emotional investment in favour of liberalisation (Jones 2015, 25). Moreover, they can also reproduce a country's ideational motivation to be associated with a set of global standards that confer status or prestige, such as most developed countries, top environment-friendly economies, among others (Meyer at al. 1997, 145; Jones 2015, 26).

For Calvert Jones, these moves are social engineering policies or «efforts by state elites to mold the culture of the societies they rule» $(2015,27)$. Investigating this phenomenon in the United Arab Emirates, she claimed that the rulers aim to project a more modern country and reduce pressures on the state while corresponding to their personal positive western experiences. Carvalho Pinto $(2019,6)$ argued that Emirati rulers use women's rights deliberately to seek higher status vis-à-vis other Arab states, improving their position on western perception on topics such as gender and human rights. AlRasheed $(2013,21)$ also stressed this connection between women's emancipation and international standards, illustrating how the $9 / 11$ attacks pressured Saudis for more inclusive policies tackling radicalism within the society.

Thus, liberalising measures in autocratic states are connected with the quest for status. Larson, Paul and Wohlforth $(2014,7)$ defined status as collective beliefs about global ranking on valued attributes. Status is positional, as it refers to standing in a given area; it is social, as it depends on the recognition of others; and it is subjective, as there is no time-variant formula for what qualifies or which attributes confer status (Renshon 2017,4). A state's estimative of its status is based on the interpretation and acceptance of others, a judgement that may leave it either satisfied or dissatisfied with what has been ascribed (Larson, Paul, and Wohlforth 2014, 8). 
A country dissatisfied with its ascribed status develops policies to alter it and boost its position (Larson, Paul, and Wohlforth 2014; Renshon 2017). Status is a significant source of soft power: the better the ranking, the broader the opportunities for expanding interests and influencing others (Renshon 2017, 2). Thus, an increased status results in access to resources that were not available before. Status-seeking behaviour, hence, means that a country is attempting to inform others about its ambitions to gain a better international position. It does that via diplomatic activity, global platforms and meetings, repeated statements and speeches, acquisition of symbols, among others (Larson, Paul, and Wohlforth 2014, 22; Carvalho Pinto 2019, 4).

In this point, it should be clear the interconnection between status and liberal autocratic moves. Personal and ideational motivations of autocracies to push for liberalisation reflect the wish to belong to a selective grouping or to correspond to global norms of society, reducing pressure over the regime (Jones 2015, 24). As nowadays the international standard for more «advanced civilisations» includes women empowerment (Towns 2009), top-down policies oriented to provide more freedom to women reflect manners in which autocratic regimes seek for higher global ranking. The next session explores how Saudi Vision 2030 contemplates both phenomena to different audiences.

\section{The Salmans' vision}

Saudi Arabia is a leading energy producer and has overall positive relations with regional and global actors (Hertog 2018; Partrick 2018). However, it ranks low in many issues valued by the international community, such as social-political freedom, democracy and human rights (Niblock 2006). It is a dynastical monarchy built on conservative Wahhabi values and with a weak civil society in terms of political participation (Niblock 2006; AlRasheed 2013). The religious constituency has far-reaching control over social norms and costumes, giving the Saudis an international image of a conservative society that does not welcome foreign innovations (AlRasheed 2013).

The kingdom is a prime example of a rentier system as its economy depends significantly on the rents of energy resources, incorporating only a fraction of the society on the production of revenues. The state, as the primary recipient of the wealth, redistributes it via a heavily subsidised welfare-state (Gause 2018, Krane 2019). This system produces a social contract where the population yields political participation in return for public goods (Ennis 2019). However, while the rentier social contract has worked for decades in Saudi Arabia, it is today more and more associated with bureaucracies that are often corrupt, mounting state's debt, growing unemployment and a small, inefficient private sector (Hertog 2018, 7380). 
The growing insufficiency of the rentier social contract became more urgent with the drop in oil prices after 2014, the leading cause of Saudis mounting budget deficits (Hertog 2018; Krane 2019, 124). Simultaneously, the country has one of the highest birth rates in the world, and there is a growing dissonance between the tech-savvy youth, the ageing ruling elites and the conservative religious establishment (Alhussein 2019, 6). In sum, the economy is not growing on the same pace as the population, which is increasingly less willing to accept the traditional institutions of rule and perceiving the regime as «slow to react and resistant to change» (Gause 2018, 36).

Vision 2030 aims to deal with these economic constraints by transforming the country into a regional financial hub, a giant of the downstream petrochemicals, and a more capital-attractive economy (Hertog 2018; Grand 2019). MBS is promoting it in meetings in Asia, Europe and the US and consulting presidents and CEOs of global companies. To reach this pursued status of a most exceptional Middle Eastern economy, Riyadh must attract foreign investment, tourism, international capital and global companies, improving, thus, the country's overall international position.

The plan also aims to confront the traditional civil-state relations by linking economic participation with a social duty towards the «new nation» (Doaiji 2017; Alhussein 2019). MBS is nurturing a nationalism (frequently called Hazm, decisive) defined by a sense of pride to be Saudi and to be part of the change, always underlining the importance of the youth on the construction of the upcoming country. Vision 2030 calls for «taking pride in our national identity», (Kingdom of Saudi Arabia 2017, 17) «strengthening the sense of national belonging and fostering the values of tolerance, moderation, perseverance and determination» via «values of entrepreneurship, generosity, volunteering, excellence, hard work, ambition and optimism» (Kingdom of Saudi Arabia, n.d.).

A crucial point about this Hazm nationalism is its detachment from the traditional religious nationalism (Doaiji 2018, 130). For decades, the clerics had assisted state stability by providing an identitarian narrative of union (AlRasheed 2013; Darwish 2014). However, the young population, the world's top per-capita consumer of Youtube videos and vastly present in social media, is growing disconnected from this constituency (Alhussein 2019, Krane 2019, 123). The crown prince seems to impersonate this disconnection, representing a fast-pace Millenium generation, talking about al-saoudiyya al uthma (Great Saudi Arabia), criticising Islamic hardliners and comfortable using western suits and shaking women hands (Krane 2019, 122).

Thus, I argue that Vision 2030 is a social-engineering manoeuvre tackling tensions on the rentier social contract to recalibrate the regime's legitimacy. It is in this context that Saudi women scored their most significant victory yet, which is the right to drive, discussed in the next sections. I argue that this event is a compelling case study of the symbiotic relationship between autocratic liberal- 
isation and status-seeking behaviour. While the lift of the ban corresponded to international standards of modernisation, it also relates heavily with the nationalist rhetoric.

\section{Saudi women and the right to drive}

Saudi women have been submitted to a harsh regulation system that controls their bodies and freedom, not enjoying the full benefits of citizenship or legal adulthood (AlRasheed 2013). The male guardianship system has institutionalised gender discrimination on every social interaction under the belief that men are physiological and emotionally superior (Aldosari 2016). There is no law prescribing this system, which is based on customary practices and fatwas curtailing their freedom of movement and choice (Duomato 2005; Poméon 2018, 9). There is also no definition of legal majority, and they remain minors for life, reliant on their family to enrol at university, access justice department, divorce and others.

Saudi women's exclusion is associated with the country's political history. The 1979 Iranian Islamic Revolution and the 1980 Siege of Mecca increased the regime's threat perception, as they challenged the monarchical rule, domestic and internationally (Darwish 2014). As a response, Saudi Arabia enhanced the authority of the Islamic establishment, and, in this process, women became the focus of the religious police (Mutawa): protecting them from «vice» and «immorality» meant more prohibitions (Niblock 2006, 66). Saying that women were «privileged queens» and «unwrapped candies that must remain covered» or else «chaos would be upon the society», the state increased the control over women's bodies (Doaiji 2017).

The ban on driving represents an epitome of this gendered regime. While there are plenty of other limitations over their bodies, the majority of women's complaints has been associated with driving (Poméon 2018, 12). The country's geography imposes obstacles to movement due to the desert climate and long distances. Thus, the ban reduced women's mobility and work possibilities. It also affected men, as they are socially compelled to drive their wives, mothers or sisters to appointments (Doumato 2005). Many families employ foreigners as chauffeurs, which increases household expenses. The driving ban, thus, hampers Saudi economy in three different lines: restricts women access to jobs, reduces men productivity and frustrates measures of nationalising the working force.

In 1990, forty-seven women drove around Riyadh in protest after seeing American female soldiers driving. They suffered backlash immediately, were forced to sign a document that they would never drive again, had their passports confiscated, and a list with their names was published for shaming. Immediately, the Grand Mufti declared a fatwa against woman driving, stating that it would expose them to «temptation» (Aldosari 2016). For more than a decade, women felt 
frightened to protest as the Mutawa was now institutionally supported (Doaiji 2018: 120).

In 2011, an emerging group of women activists campaigned on social media for driving, using hashtags that allowed women from all the country and expats to participate in debates on the guardianship system (Doaiji 2018: 121). Activist Manal al-Sharif was one of the launchers of \#Woman2Drive campaign, and, to encourage others, she released a video of herself driving. She was arrested, lost her job and the custody of her son, finally self-exiling for fear of further prosecution. Around 60 women drove and posted videos to support al-Sharif. Daring to drive thus became a symbol of change for many women (AlRasheed 2013, 291; Alhussein and Al-Sudairi 2019).

Names such as Wajeha al-Huwaider, Loujain al-Hathloul and Fawzia al-Oyouni went viral as they disobeyed the rules, filming themselves driving, funding illegal NGOs or submitting petitions for ending the guardianship system. Since then, acts of female defiance turned more frequent (Aldosari 2016). Women were involved in general discussions over democracy, adopting a broader political project concerning their status and relationship with the public sphere (Doaiji 2018, 123). They staged marches demanding the release of political prisoners (AlRasheed 2013 , 287), increased online targeting of the guardianship system and demanded greater freedom of choice (Alhussein and AlSudairi 2019).

In July 2016, Human Rights Watch released the report 'Boxed In' about the guardianship system, which provided the ignition of another wave of hashtags protests such as \#IamMyOwnGuardian. Saudi female activists used social media to increase demands and target the guardianship system, arguing that the gendered regime restricted their freedom and public role (Alhussein and AlSudairi 2019). Quickly, the campaign surpassed the control of the known feminist activists and morphed into a much broader movement (Doaiji 2018). It multiplied and dispersed the set of concerns, consequently challenging the ownership of the campaign and further dividing women (Doaiji 2017).

Historically, women had bargained with the state for their benefit by blaming it for their difficulties or the restrictiveness of Wahhabism (in the case of liberal women) or the spiritual corruption of tribal roots (in the case of Islamist women) (AlRasheed 2013, 30-33). In other words, both liberal and Islamist women did not challenge the state, as they found the source of their problems within the structure of society. What Aldosari (2017) and Doaiji $(2018,121)$ argued was that the 2011-2014 activists rejected the patriarchal bargain as their grievances shifted from society to the state. These women were directly confronting the regime by breaching the law, posting against the government and directly criticising stateled oppression.

However, the rise of Hazm nationalism opened space for another type of negotiation, in which women used the idea of social responsibility to question how they could contribute to the upcoming modern Saudi Arabia. Hazm women 
asserted themselves as «true Saudi citizens», evoking a womanhood backed by notions of patriotism and loyalty (Doaiji 2018, 140-141). Eventually, they distinguished themselves from the other campaigners from 2011-2014, again refusing to blame the state, and became key to Vision 2030, as explained in the next session.

\section{Hazm Women and Saudi Vision 2030}

AlRasheed reasoned that oil wealth has allowed the Saudi state to exclude women from the workforce and that «real change will come only when the economy cannot function without them» $(2013,24,292)$. The redistribution of oil revenues both permitted and maintained a system where men were the sole breadwinners and women just recipients of financial support (Al Rasheed 2013: 23). Now, with the constrained economy, it is getting harder for families to have only one source of income (Krane 2019, 124). The liberalisation measures, thus, including the right to drive, should be understood as corresponding to rentier social-contract limitations, reimagining it on a post-oil society (Ennis 2019, 61).

Saudi Vision 2030 reflected the prescriptions of a government-ordered McKinsey's report on the country's economy. This consulting firm concluded, among other things, that a crucial factor for reaching the post-oil objective was to include women in the workforce, countering the inescapable reduction in household income (AlKibsi et al. 2015). Hence, diversifying the economy depends on women becoming consumers and workers (Ennis 2019, 60). It also recommended removing restrictions on driving as it identified transportation as a critical impediment for female labour (Aldosari 2016; AlKibsi et al. 2015). Vision 2030 plans to «increase women's participation in the labor market» from 17\% in 2017 to 25\% in 2020 (Kingdom of Saudi Arabia 2018, 82).

Gulf women are seen as an «untapped resource» for economic growth (Ennis 2019, 61). To Aldosari (2016), challenges to economic participation are embedded in political rather than cultural restrictions, as recent efforts to feminise particular job areas (such as retail), led to a remarkable increase in employment without societal resistance. In Saudi Arabia, female university graduates outnumber men, but only $18 \%$ of women at working-age are employed (Aldosari 2016). Jobs are concentrated in gender-segregated areas, such as public education and healthcare. MBS said that «a large portion of my productive factors are unutilized», referring to «women in the workforce». ${ }^{2}$ On the Vision 2030 documents, the words «women» and «womanhood» are all related to economy; for instance, «with over 50 per cent of our university graduates being female, we will continue to develop their talents, invest in their productive capabilities» (Kingdom of Saudi Arabia 2017, 37).

2 «Transcript: Interview with Muhammad bin Salman», The Economist, January 6, 2016. Available at: <https: / / www.economist.com/middle-east-and-africa/2016/01/06/transcript-interviewwith-muhammad-bin-salman>. 
Here is where the Hazm womanhood comes in handy for MBS' ambitions. By evoking concepts of citizenship, these women labelled themselves as "patriotic feminists», refusing to be used against the state while bargaining for rights (Doaiji 2018, 142-143). Women discussed on Twitter about their role in Saudi's economic development, praising the King and MBS and their achievements (Fareed 2018). Haifa al-Zahrani, a female war journalist, stated that «women can reach anywhere, as long as they do not challenge the state and its laws» (Doaiji 2018, 132). Journalist Aisha Fareed (2018) proudly said that: «We are not late. We are not early. We are very much on time», concluding with «dear world, please fasten your seatbelts and take the back seat while we drive the wheel of change our own way».

This way, the regime co-opts women into modernisation via a sense of pride, which, in turn, helps the implementation of the needed reforms. In other words, by involving women in the modernisation project via nationalism, MBS taps on their economic potential without empowering them politically. The male-dominated structure is far from being challenged, as there is no holistic reform seeking to reduce the drastic gap between men and women (Aldosari 2017). Despite what AlRasheed predicted, the recognition of woman labour's importance has not, so far, redirected «real change». Autocratic liberalisation does not represent democratisation, but accommodation of the social contract for rule continuity (Brumberg 2002). The liberalisations are a marriage of convenience between rentierism and autocratic liberalisation, using both women economic enablement to promote private sector growth, diversification and development without making the state less sexist (Ennis 2019, 62).

\section{Authoritarianism and the limitations of status-seeking}

Status has a double-edged characteristic: it can improve a country's position, but it can also put a spotlight on other matters that were once concealed, producing unexpected side effects that can eventually harm status-seeking policies (Larson, Paul, and Wohlforth 2014). Thus, even though the prohibition of driving was a well-known fact, Saudi women were never in the media's spotlight as they have been since the end of the ban. This final section argues that liberalisations through exclusionary social engineering can negatively impact status ambitions as all nationalist collective projects are by nature sectarian. While international and local media, without exception, praised the empowerment of women, many of them had also stressed the limitations of the nationalist project to which these liberalisations belong to.

MBS' project comprises political personalisation, meaning the concentration of power on his hands, reduction of the authority of other political elites and heavy use of propaganda and cult of image (Diwan 2018; Gause 2018). In this move, he is excluding dissidents and critics of the narratives of belonging by fram- 
ing them as traitors of the nation (AlRasheed 2018a). He is also increasing surveillance apparatus and social media spies (Poméon 2018, 29). Arrests, indefinite detentions, delayed court appearances, death penalties and public beheadings have escalated. Only between September and October 2017, more than seventy people were arrested, most of them preachers, activists, bloggers, intellectuals and journalists that accused authorities of violating human rights (Poméon 2018, 6). Torture, elimination and violence are normalised in the name of a collective will (Al Rasheed 2018b).

This is where Hazm womanhood enters the picture. By promoting a «right kind' of women rights» activists, both patriotic and collaborative, these women became complicit of a political crackdown against others that blame the state for their exclusion. Hazm feminism calls other feminists «radical», even compare them with ISIS, saying that they are «the second face of the devilish currency, no less dangerous» that promotes «hostile political movements» in which freedom is to do "what she [women] wants without teaching her to preserve her dignity» (Muzafar 2019). They also reject foreigners, expatriates, LGBTQ+, or atheists as defectors and turncoats, not corresponding to the majority of Saudi woman (Doaiji 2018, 143).

Many activists who campaigned against the driving ban are now in prison or under threat of prosecution because they have asked for more substantive reforms (AlRasheed 2019). Loujain AlHathloul, a known activist that filmed herself driving, was arrested for a second time in May 2018 under dubious charges of spying and has been reportedly tortured and harassed (Jamal 2019). Another driver and anti-guardianship activist, Samar Badawi, is imprisoned since July 2018 with no trial in sight. Runaways are also a target, being arrested and returned to their families when attempting to flee (Poémon 2018, 41). Anti-guardianship activist Alaa AlAnayzi was detained at the airport waiting for Dina Ali Lasloom's forced return after she was caught escaping. Twitter activist Marian Al Otaibi was arrested on April 2017 under the charges of disobedience and «breach of the peace». Also, those that left the country and became voices against the regime, such as Manal al-Sharif, are disqualified by the Hazm women as «just women tweeting from outside the country, cursing the government» (Doaiji 2018, 142). ${ }^{3}$

These stories have been harming Saudi's image internationally and hampering the goals for higher status. Increasing discussion on violations of human rights has embarrassed some countries with links to Saudi Arabia, especially after the October 2018 assassination of journalist Jamal Khashoggi. For example, in November 2018, after rumours that Samar Badawi would be sentenced to the death penalty, the Canadian Foreign Affairs Ministry tweeted that it was "gravely concerned about additional arrests of civil society and women's rights

On her article, Doaiji (2018) presented the results of many interviews and analysis of Twitter feeds from women that self-identified themselves as Hazm feminists. 
activists» (Coletta and Fahim 2018). Riyadh responded suspending diplomatic ties. The tension increased again in January 2019, when Canada granted asylum to Saudi teenager Rahaf al-Qunun, who was caught in Bangkok while escaping her guardian. Spain, Iceland, Sweden, Slovenia, Switzerland, and New Zealand also issued recommendations to abolish male guardianship, starkly criticising the regime's repression.

My main argument is that social engineering measures with excluding nationalist narratives will, in one way or another, limit the possibilities for higher international status as the standard of civilisation referring to women is inclusive - it does not specify which women should or should not be empowered (Towns 2009). International actors are hearing the voices (or the silence) of these dissident women. In 2019, Loujain AlHathloul was named Time magazine's 100 most influential people. Amnesty International called 2018-2019 the 'year of shame for Saudi Arabia', and the stories of these women are becoming viral, pressuring the international community for reactions. ${ }^{4}$

Names of Saudi arrested activists are now widely known, and the majority of news on any reform published since 2018 has at least a line remembering the readers that these women are still in jail. Projecting women entrepreneurship and economic empowerment is a way of gaining more international status, which is crucial for the long-term success of Vision 2030. Nevertheless, the growing distinction between the right and the wrong kind of women activism will just hamper this endeavour. In sum, the regime's growing authoritarianism and Hazm nationalism low tolerance for criticism obstruct the pursuit for international status.

\section{Final remarks}

Saudi Arabia has, undoubtedly, transformed since the rise of King Salman and his son to power. The Crown Prince seems to be in a rush to rebuild his country into a modernised nation, as a way to consolidate his hold on power and improve Riyadh's international position. I argued in this paper that his broad reform project, Vision 2030, is a social engineering program that aims to alter the contract that rules the relation between state and society and that women are a crucial factor in this equation. Vision 2030 responds to two audiences, the domestic and the international one: in the local level, it is an autocratic liberation move to guarantee regime legitimacy; for the global eyes, it is a status-seeking behaviour. I used the liberalisations for women, focusing on driving, to show the limitations between these two ambitions, without ignoring the roles that women can play while bargaining with the state.

$4 \quad$ Available at: <https://www.amnesty.org/en/latest/news/2019/05/saudi-arabias-year-ofshame-crackdown-on-critics-and-rights-activists-continues $>$. 
The concept of Hazm nationalism is crucial for my argument. While the development of this nationalism, somewhat dissociated from the religious constituencies, mobilises society in favour of the reforms and provides a new source of legitimacy for the authoritarian regime, its incapability to deal with dissent inevitably damages the pursuit for greater international status. MBS' popularity is high, especially among the youth (Grand 2019); however, his international image is tarnished, mainly due to Khashoggi's assassination and the growing arrests of women activists. If, by 2017, many were enthusiastic with his views on modernisation, now he is frequently regarded as a 'reckless' and 'impulsive' leader (AlRasheed 2018b; Gause 2018).

The Saudi case is thought-provoking because many of the women that had been for a long time fighting for the right to drive are not the primary beneficiaries of the decree and they were stripped of ownership of the changes, at least on the official nationalist narrative. That is not necessarily an exception, as, in authoritarian regimes, women liberalisation movements tend to be understood in the limits of the state, with the government initiating and driving the reforms that may improve their lives, but that do not provide political empowerment. Nevertheless, as long as these women are not integrated into society as legit citizens with political representation and recognition, Saudi Arabia's aspiration to receive a higher international status is bound to fall short.

\section{References}

Aldosari, Hala. 2016. «The Saudi National Transformation Program: what's in it for women?», The Arab Gulf States Institute in Washington, February 2. Available at: https:/ / agsiw.org/the-saudi-national-transformation-program-whats-in-it-for-women / [access 06.06.2019]

Aldosari, Hala. 2017. «All the King's women: new Shura Council members stir gender debate», The Arab Gulf States Institute in Washington, May 11. Available at: https:/ / agsiw.org/kings-women-new-shura-council-members-stir-gender-debate/ [access 06.05.2019]

Alhussein, Eman. 2019. «Saudi First: how hyper-nationalism is transforming Saudi Arabia», European Council on Foreign Relations (ECFR): Policy Brief, 1-19.

Alhussein, Eman; Mohammed Al-Sudairi. 2019. «Parallels between feminist movements in Saudi Arabia and China», Arab Gulf States Institute in Washington, July 30. Available at: https: / / agsiw.org / parallels-between-feminist-movements-in-saudi-arabia-and-china/ [access 29.09.2019]

Al-Kibsi, Fassan et al. 2015. «Moving Saudi Arabia's economy beyond oil», McKinsey Global Institute. December. Available at: https://www.mckinsey.com/featured-insights / employment-and-growth/moving-saudi-arabias-economy-beyond-oil [access 06.05.2019]

Al-Rasheed, Madawi. 2013. A Most Masculine State. Cambridge: Cambridge University Press. 
Al-Rasheed, Madawi. 2018a. «Mystique of monarchy: the magic of royal succession in Saudi Arabia» In AlRasheed, Madawi (eds): Salman's Legacy: the dilemmas of a new era in Saudi Arabia, London: Hurst \& Company, 45-73.

Al-Rasheed, Madawi. 2018b. "After Khashoggi, the myth of the benign Arab monarchy is dead», Middle East Eye, 31 October. Available at: https:/ / www.middleeasteye.net/ opinion/after-khashoggi-myth-benign-arab-monarchy-dead [Access 10.05.2019].

Al-Rasheed, Madawi. 2019. «Saudi men and women are now equal - when it comes to prison torture», Middle East Eye, 8 March. Available at: https: / / www.middleeasteye. net/opinion/saudi-men-and-women-are-now-equal-when-it-comes-prison-torture [Access 10.05.2019]

Al-Sharif, Manal. 2019. «We finally won the Right to Drive in Saudi Arabia. But the Kingdom's war on women is only getting worse». Time, April 10. Available at: http:/ / time. $\mathrm{com} / 5567330$ / saudi-arabia-women-rights-drive [access 04.05.2019]

Brumberg, Daniel. 2002. «Democratization in the Arab World? The Trap of Liberalized Autocracy». Journal of Democracy 13 (4): 56-68. DOI: https://doi.org/10.1353/ jod.2002.0064

Carvalho Pinto, Vânia. 2019, «Signalling for status: UAE and women's rights». Contexto Internacional 41 (2): 345-357. DOI: https: / / doi.org/10.1590/ s0102-8529.2019410200006

Coletta, Amanda, and Kareem Fahim. 2018. «Saudi Arabia expels Canadian ambassador after Ottawa criticizes arrests of Saudi activists», Washington Post, August 6. Available at: https:/ / www.washingtonpost.com/world/middle_east/saudi-arabia-expels-canadian-ambassador-after-ottawa-criticizes-arrests-of-saudi-activists / 2018/08/06/99 df2714-9945-11e8-8d5e-c6c594024954_story.html [Access 12.04.2019].

Darwish, May. 2014. "The ontological (in)security of similarity: Wahhabism versus Islamism in Saudi Foreign Policy». GIGA Policy Papers 263: 1-26. Retrieved from https:/ / www.giga-hamburg.de/en/system/files/publications/wp-263-online.pdf

Diwan, Kristen. 2018. «Saudi nationalism raises hope of greater Shia inclusion», Arab Gulf States Institute in Washington, May 3. Available at: https:/ / agsiw.org/saudi-nationalism-raises-hopes-greater-inclusion-shias [access 11.04.2019]

Doaiji, Nora. 2017. «Saudi Women's online activism: one year of the 'I am my own guardian' campaign», The Arab Gulf States Institute in Washington, Issue Paper 11.

Doaiji, Nora. 2018. «From Hasm to Hazm: Saudi feminism beyond Patriarchal bargaining», In AlRasheed, Madawi (eds): Salman's Legacy: the dilemmas of a new era in Saudi Arabia, London: Hurst \& Company, 117-147.

Doumato, Eleanor. 2005. Women's Rights in the Middle East and North Africa - Saudi Arabia, Freedom House, October 14. Availableat: https: / / www.refworld.org/ docid / 47387b6f2f. html [access 6.06.2019]

Ennis, Crystal. 2019. «Rentier-preneurship: dependence and autonomy in women's entrepreneurship in the Gulf», The Politics of Rentier States in the Gulf, PMES Studies, 33, 60-67.

Fareed, Aisha. 2018. «Woman driving in KSA: a huge milestone not a baby step», Arab News, July 2. Available at: https://www.arabnews.com/node/1332226/saudi-arabia [Access 29.09.2019].

Friedman, Thomas. 2017. «Saudi Arabia's Arab Spring, at last», The New York Times, November 23. Available at: https:/ / www.nytimes.com/2017/11/23/opinion/saudi-princembs-arab-spring.html [access 05.06.2019] 
Grand, Stephen. 2019. 'The Khashoggi Killing through Saudi Eyes'. Atlantic Council, March 21. Available at: https://www.atlanticcouncil.org/blogs/menasource/the-khashoggi-killing-through-saudi-eyes [access 12.02.2019]

Gause, Gregory. 2018. «Saudi regime stability and challenges». In: AlRasheed, Madawi (eds): Salman's Legacy: the dilemmas of a new era in Saudi Arabia, London: Hurst \& Company, 31-45.

Hertog, Steffen. 2018. «Challenges to the Saudi Distributions State in the age of austerity». In: AlRasheed, Madawi (eds): Salman's Legacy: the dilemmas of a new era in Saudi Arabia, London: Hurst \& Company, 73-97.

Jamal, Urooba. 2019. ‘One year later, justice for my friend Loujain al-Hatholoul means a full pardon from Saudi authorities', Independent, April 20. Available at: https://www. independent.co.uk/voices / loujain-al-hathloul-saudi-arabia-prison-charges-nobelprize-campaign-a8879421.html [access on 06.06.2019]

Jones, Calvert. 2015. «Seeing like an autocrat: liberal social engineering in an illiberal state», Perspectives on Politics, 24-40. Retrieved from https: / / www.researchgate.net/ publication/276705171_Seeing_Like_an_Autocrat_Liberal_Social_Engineering_in_an_Illiberal_State

Jones, Calvert. 2019. «Social engineering in rentier states», The Politics of Rentier States in the Gulf, PMES Studies, 33, 67-72.

Kingdom of Saudi Arabia. n.d. National Character Enrichment Program. Available at https: / / vision2030.gov.sa/en/programs/NCEP

Kingdom of Saudi Arabia. 2017. Saudi Vision 2030. N.p: Kingdom of Saudi Arabia. Available at https://vision2030.gov.sa/sites/default/files / report/Saudi_Vision2030_EN_2017. pdf

Kingdom of Saudi Arabia. 2018. National Transformation Program. Delivery Plan 2018-2020. N.p.: Kingdom of Saudi Arabia. Available at https: / / vision2030.gov.sa/ sites / default / files / attachments / NTP\%20English\%20Public\%20Document_2810.pdf

Krane, Jim. 2019. Energy Kingdoms. New York: Columbia University Press.

Larson, Deborah Welch, T. V. Paul, William C. Wohlforth. 2014. Status in World Politics, Cambridge: Cambridge University Press.

Levitsky, Steven; Lucan Way. 2010. Competitive Authoritarianism: Hybrid Regimes after the Cold War. Cambridge: Cambridge University Press.

Meyer, John W; John Boli; George Thomas; Francisco Ramirez. 1997. «World Society and the Nation-State», American Journal of Sociology 103 (1): 144-181. DOI: https:// doi. org / 10.1086/231174

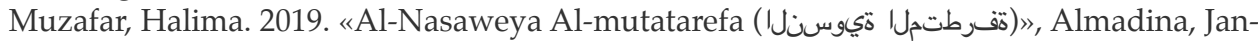
uary 20. Available at: https:/ / www.al-madina.com/article/610193 [Access on 27.09. 2019]

Niblock, Tim. 2006. Saudi Arabia: power legitimacy and survival. NY: Routledge.

Partrick, Neil. 2018. Saudi Arabian Foreign Policy. New York: I.B. Tauris.

Poméon, Alexandra. 2018. «Saudi Arabia: condemned to silence the situation of women human rights defenders», The Observatory for the Protection of Human Rights Defenders.

Renshon, Jonathan. 2017. Fighting for status. Hierarchy and conflict in world politics. Princeton and Oxford: Princeton University Press.

Towns, Ann. 2009. "The status of women as a standard of "civilisation"», European Journal ofInternationalRelations15(4):681-706.DOI:https: / / doi.org/10.1177/1354066109345053 
Luíza Cerioli. Doctoral Researcher at the Centre for Near and Middle Eastern Studies (CNMS) at the University of Marburg, Germany. She holds a Master in International Relations from the University of Brasília. Her PhD focuses on the triangular relations between Iran, Saudi Arabia and the United States. Her main fields of research are the Persian Gulf, with a focus on Iran and Saudi Arabia, regional powers and US' Middle Eastern foreign policy.

Electronic address: luizacerioli@gmail.com

Article received on the $23^{\text {rd }}$ of June and accepted for publication on the 30 $30^{\text {th }}$ of September 2019. 